\title{
ENZYME-LINKED IMMUNOSORBENT ASSAY (ELISA)-BASED-SENSOR FOR DETERMINATION OF BENZO[A]PYRENE IN RIVER WATER USING SCREEN-PRINTED GOLD ELECTRODE
}

\author{
(Sensor-berasaskan Ujian Enzim-Pengerap Immuno (ELISA) untuk Pengesanan Benzo[a]pirina \\ dalam Air Sungai Menggunakan Elektrod Emas Skrin Tercetak)
}

Noor Sheryna Jusoh, Alyza Azzura Abd Rahman Azmi, Azrilawani Ahmad*

School of Marine and Environmental Sciences, Universiti Malaysia Terengganu, 21030 Kuala Terengganu, Terengganu, Malaysia

*Corresponding author: azrilawani.ahmad@umt.edu.my

Received: 16 August 2016; Accepted: 15 April 2017

\begin{abstract}
This paper described the surface modification of screen-printed gold electrode using thiol self-assembled monolayer, in combination with enzyme-linked immunosorbent assay (ELISA) format for determination of benzo[a]pyrene (BaP) in water sample. All biomolecules were immobilized on the surface of working electrode to increase the sensitivity of the developed biosensor by applying different types of ELISA. Electrochemical characterizations using cyclic voltammetry (CV) and electrochemical impedance spectroscopy (EIS) were carried out to study the conductivity behavior of the developed biosensor. Based on the results, biomolecules were successfully immobilized and characterized optically and electrochemically. Optical immunoassay with indirect competitive ELISA were developed for the determination of BaP compound which showed the best performance compared to other assay. In optical measurement, normal assay exhibits higher absorbance, implying high bio complex formation. Modification of electrode using 11-MUA was successful due to highest blocking effect for electron transfer process. Determination of $\mathrm{BaP}$ in real water samples shows that there no $\mathrm{BaP}$ was detected in all samples collected, due to no presence of $\mathrm{BaP}$ in all samples.
\end{abstract}

Keywords: surface modification, screen-printed gold electrode, benzo[a]pyrene, water sample

\section{Abstrak}

Kertas kerja ini menerangkan pengubahsuaian permukaan elektrod emas skrin tercetak menggunakan lapisan mono tepasang menggunakan tiol, dengan kombinasi format ujian enzim-pengerap imuno (ELISA) untuk penentuan benzo[a]pirina (BaP) dalam sampel air. Semua molekul bio telah dipegunkan di atas permukaan elektrod bekerja untuk meningkatkan kepekaan biosensor yang dibangunkan dengan menggunakan pelbagai jenis ELISA. Pencirian elektrokimia menggunakan voltametri kitaran (CV) dan spektroskopi impedans elektrokimia (EIS) telah dilakukan untuk mengkaji tingkah laku kekonduksian biosensor yang dibangunkan. Berdasarkan keputusan yang diperolehi, molekul bio telah berjaya dipegunkan dan dicirikan secara optik dan elektrokimia. Ujian imuno optik dengan ELISA bersaing secara tak langsung telah dibangunkan untuk penentuan sebatian BaP menunjukkan prestasi terbaik berbanding ujian lain. Dalam pengukuran optik, ujian normal mempamerkan keserapan lebih tinggi, menandakan pembentukan kompleks bio yang tinggi. Pengubahsuaian elektrod menggunakan 11-MUA berjaya disebabkan oleh kesan halangan tertinggi bagi proses pemindahan elektron. Penentuan BaP dalam sampel air sebenar menunjukkan tiada $\mathrm{BaP}$ dikesan dalam semua sampel yang diambil, kerana ketiadaan $\mathrm{BaP}$ dalam semua sampel.

Kata kunci: pengubahsuaian permukaan, elektrod emas skrin tercetak, benzo[a]pirina, sampel air 


\section{Noor Sheryna et al: ENZYME-LINKED IMMUNOSORBENT ASSAY (ELISA)-BASED-SENSOR FOR DETERMINATION OF BENZO[A]PYRENE IN RIVER WATER USING SCREEN- PRINTED GOLD ELECTRODE}

\section{Introduction}

Rapid growing of industries has contributed in the increasing of organic pollutants in the environment. Among the pollutants, polycyclic aromatic hydrocarbons (PAHs) have gained extra attentions in the past years from countless research in various fields. PAHs exist naturally in the environment through a carbonization process or can be manmade by pyrolytic processes [1]. However, most of the PAHs compounds in the environment today are the products from the infinite growing industries and human activities and they enter the environment through the incomplete combustion of fossil fuels such as crude oil or coal. Some compounds of PAHs have been recognized as carcinogenic, mutagenic and teratogenic. The simplest PAHs structure is naphthalene, which is the main ingredient in 'moth ball' or 'naphthalene ball', used to get of insects in closet.

Chromatographic technique such as liquid and gas chromatography were frequently selected to detect PAHs compounds in environment, especially in water samples. The method was certainly convenient for determining many targets analytes at one time, in addition of giving precise and accurate results. However, this method usually required large number of samples and complex sample preparation, which is time consuming. Thus, a lot of studies were conducted to develop simpler methods, yet give good results. The new developed method includes biosensor and immunosensor. Biosensors are analytical devices which are fabricated from the combination of two parts: a biological recognition element such as an antibody, enzyme, receptor, DNA, or cell and transducer that converts the biorecognition process into a measurable physical signal [2]. Immunosensors are one of the biosensors, which are widely investigated and developed over these past years. An immunosensor is an affinity-based biosensor designed to detect the direct binding of an antibody or an antigen [3]. The biological reactions on the surface of electrode will be detected by transducer and then converted into physical signal.

Enzyme-Linked Immunosorbent Assay (ELISA) principle is often used for immobilization of antibodies and antigen in immunoassay for biosensors development. The steps in ELISA involve the attachment of antigens to the surface, the application of antibody to the antigen, the antigen-antibody reactions and finally the addition of substrate. ELISA comes in several types namely indirect, direct, sandwich and competitive ELISA. ELISA is broadly applied in medical [4-6], food industry [7, 8], beverage industry [9] and environmental fields, for example detection of dioxins [10] and PAH compounds $[11,12]$.

In this study, we focused on the application of ELISA for detecting benzo(a)pyrene (BaP) in river water samples. Biological elements such as coating conjugate and antibodies were immobilized in 96-well plate and on the screenprinted gold electrode (SPGE) using indirect competitive ELISA. This type of assay is commonly applied for determination of 1-hydroxypyrene [13] and phenanthrene [14] because the assay usually gave higher sensitivity results compared to other assays. The performance of the immobilized biomolecules were measured optically and electrochemically. The purpose of this study is to determine the behavior of immobilized biomolecules on the SPGE as well as to test the sensitivity of the competitive assay towards real water samples. Optically, a normal competitive assay would display high selectivity and sensitivity towards BaP due to the interaction of 4D5 monoclonal antibody with $\mathrm{BaP}$ molecule. In addition, low current and high resistance were expected for electrochemical measurements due to thick layer embedded on the electrode surface, resulting a slow diffusion of redox probe ions.

\section{Chemical and materials}

\section{Materials and Methods}

Screen-printed gold electrode (SPGE) C220BT were purchased from DropSens, Spain. 11-mercaptoundecanoic acid (11-MUA), ethanol, isopropanol, acetone and isopropanol and acetone were purchased from Merck, Germany. Tris(hydroxymethyl)aminomethane (Tris) and bovine serum albumin (BSA) were purchased from Sigma-Aldrich, USA. Tween 20, diethanolamine, potassium chloride, potassium hexacyanoferrate (III) and potassium hexacyanoferrate (II) trihydrate were purchased from Merck, Germany. $p$-nitrophenyl phosphate was purchased from Sigma, USA. Both goat anti-mouse IgG alkaline phopshatase and 4D5 monoclonal antibody (specific for benzo[a]pyrene) were from Santa Cruz Biotechnology, USA. Adipic acid dihydrazide, N-(3-dimethylaminopropyl)$\mathrm{N}$-ethylcarbodiimide hydrochloride (EDC), $N$-hydrosuccinimide (NHS), 9-phenanthrene carboxaldehyde and benzo[a]pyrene were purchased from Sigma-Aldrich, Germany. All reagents are of analytical grade or better. 


\section{Instrumentations}

All experiments involving cyclic voltammetry and electrochemical impedance spectroscopy were conducted at room temperature using AUTOLAB PGSTAT30 (Metrohm, Utrecht, The Netherlands), located at School of Ocean Engineering, UMT. SPGE was connected to the potentiostat by DRP-CAC connector (DropSens, Spain). SPGE was cleaned with Ultrasonic Cleaner JAC Ultrasonic 2010P (Jin Woo Engineering Co. Korea). Mini incubator (VWR, China) was used to incubate samples at $37^{\circ} \mathrm{C}$. Ascent Multiskan ELISA reader (Thermo Scientific, USA), located at Institute of Marine Biotechnology, UMT was used for optical characterization.

\section{Preparation of gold electrodes}

The C220BT screen printed AuE was ultrasonic cleaned with acetone by isopropanol and lastly ultrasonic cleaned in deionized water for 5 minutes in each solution, respectively [15].

\section{SAM formation on gold electrodes}

SPGE was immersed in the freshly prepared $5 \mathrm{mM} 11$-MUA in ethanolic solution for 20 hours. The modified electrode was rinsed with ethanol to remove any unbound molecules. Activation of carboxylic acid terminatedgroup was done by coupling the modified electrode with $50 \mathrm{mM}$ EDC and $50 \mathrm{mM}$ NHS and this activated-modified SPGE was further used to detect $\mathrm{BaP}$ using ELISA principle.

\section{Preparation of buffer solutions}

Blocking buffer was prepared by dissolving $0.3029 \mathrm{~g}$ Tris in deionized water. Then, the prepared solution was used to dissolve $0.5 \mathrm{~g}$ BSA. For washing buffer, $0.3029 \mathrm{~g}$ Tris was dissolved in deionized water. A total of $50 \mu \mathrm{L}$ Tris solution was pipetted out and replaced by $50 \mu \mathrm{L}$ Tween-20. $1 \mathrm{~mL} p$-nitrophenyl phosphate ( $p$-NPP) substrate was diluted in $9 \mathrm{~mL}$ of diethanolamine (DEA).

\section{Control assays}

BSA-PHEN coating conjugate was synthesized by coupling the adipic acid dihydrazide with BSA, EDC and 9phenanthrene carboxaldehyde [16]. Control assays were performed to evaluate the performance of optimized biomolecules optically and electrochemically (Table 1). $p$-NPP was only involved in optical measurement.

Table 1. Control assays

\begin{tabular}{lccccc}
\hline Assay & $\begin{array}{c}\boldsymbol{p} \text {-NPP } \\
\text { Only }\end{array}$ & $\begin{array}{c}\text { Control 1 } \\
\text { No Conjugate }\end{array}$ & $\begin{array}{c}\text { Control 2 } \\
\text { No Conjugate and 4D5 }\end{array}$ & $\begin{array}{c}\text { Control 3 } \\
\text { No 4D5 }\end{array}$ & $\begin{array}{c}\text { Normal } \\
\text { Assay }\end{array}$ \\
\hline$p$-NPP (blank) & $\sqrt{ }$ & $\sqrt{ }$ & $\sqrt{ }$ & $\sqrt{ }$ & $\sqrt{ }$ \\
AP Label & $\mathrm{X}$ & $\sqrt{ }$ & $\sqrt{ }$ & $\sqrt{ }$ & $\sqrt{ }$ \\
4D5 & $\mathrm{X}$ & $\sqrt{ }$ & $\mathrm{X}$ & $\mathrm{X}$ & $\sqrt{ }$ \\
Blocking & $\mathrm{X}$ & $\sqrt{ }$ & $\sqrt{ }$ & $\sqrt{ }$ & $\sqrt{ }$ \\
BSA-PHEN & $\mathrm{X}$ & $\mathrm{X}$ & $\mathrm{X}$ & $\sqrt{ }$ & $\sqrt{ }$ \\
\hline
\end{tabular}

\section{Indirect competitive assay for benzo(a)pyrene}

For optical characterization, the wells were coated with $50 \mu \mathrm{L}$ bovine serum albumin-phenanthrene (BSA-PHEN) coating conjugate $(n=3)$ and then incubated for an hour at $37^{\circ} \mathrm{C}$. After incubation, the plate was washed with washing buffer. $50 \mu \mathrm{L}$ blocking buffer was added into each well and incubated again for one hour at $37^{\circ} \mathrm{C}$. After that, the plate was washed again. Serial dilutions of standard BaP were mixed with 4D5 monoclonal antibody and then were left for 15 minutes to react. The solutions were prepared at concentration two times higher than the desired concentration. Then, $50 \mu \mathrm{L}$ of each solution was added into the wells and incubated at $37{ }^{\circ} \mathrm{C}$ for one hour. After washing, $50 \mu \mathrm{L}$ of alkaline phosphatase (AP) label antibody was added and allowed to react at $37^{\circ} \mathrm{C}$ for an hour. After that, the plate was washed and $200 \mu \mathrm{L}$ of $p$-NPP substrate was added into each well. The absorbance was read at $405 \mathrm{~nm}$ after 60 minutes. 
For electrochemical characterization, the working electrodes were coated with $5 \mu \mathrm{L}$ BSA-PHEN coating conjugate $(\mathrm{n}=3)$ and then incubated for an hour at $37^{\circ} \mathrm{C}$. After incubation, the electrodes were washed with washing buffer. 5 $\mu \mathrm{L}$ blocking buffer was added onto each electrode and incubated again for one hour at $37{ }^{\circ} \mathrm{C}$. After that, the electrodes were washed again. Then, $5 \mu \mathrm{L}$ of serial dilution of standard $\mathrm{BaP}$ mixed with 4D5 were added onto the electrodes and incubate at $37^{\circ} \mathrm{C}$ for one hour. After washing, $5 \mu \mathrm{L}$ of AP label antibody was added and allowed to react at $37^{\circ} \mathrm{C}$ for an hour. After one hour, the electrodes were washed and measured after 60 minutes.

$\mathrm{CV}$ measurements were carried out in $5 \mathrm{mM}\left[\mathrm{Fe}(\mathrm{CN})_{6}\right]^{3-4-}$ in $0.1 \mathrm{M} \mathrm{KCl}$ and the applied potential was in the range of -0.2 to $0.6 \mathrm{~V}$ versus $\mathrm{Ag} / \mathrm{AgCl}$. The scan rate applied was $50 \mathrm{mVs}^{-1}$. For impedance measurements, impedance behavior of the electrode is determined by analyzing the $\mathrm{AC}$ voltage and current response at frequencies ranging from $0.1 \mathrm{~Hz}$ to $10 \mathrm{kHz}$. Measurements were carried out in the presence of $5 \mathrm{mM}\left[\mathrm{Fe}(\mathrm{CN})_{6}\right]^{3-4-}$ in $0.1 \mathrm{M} \mathrm{KCl}$ at an applied potential of $+0.025 \mathrm{~V}$ with amplitude of $0.1 \mathrm{~V}$. All measurements were recorded at room temperature.

\section{Sampling site}

Water sampling was conducted at Semerak River in Tok Bali, Kelantan. The sampling was carried out in January 2016. Five sampling points were selected along the Semerak River (Figure 1). All water samples were collected using grab sampling. Triplicate of water samples were taken at each point. $1 \mathrm{~mL}$ of $2 \mathrm{M}$ nitric acid $\left(\mathrm{HNO}_{3}\right)$ was added into the water samples for preservation. Then the bottles were wrapped with aluminium foil and stored in an ice box. The bottles then were transferred into a $4{ }^{\circ} \mathrm{C}$ chiller prior further analysis.

\section{Measurements on the river water samples}

Indirect competitive assay was applied for optical and electrochemical measurements of blank and spiked (50 and 100 ppm BaP) water samples.

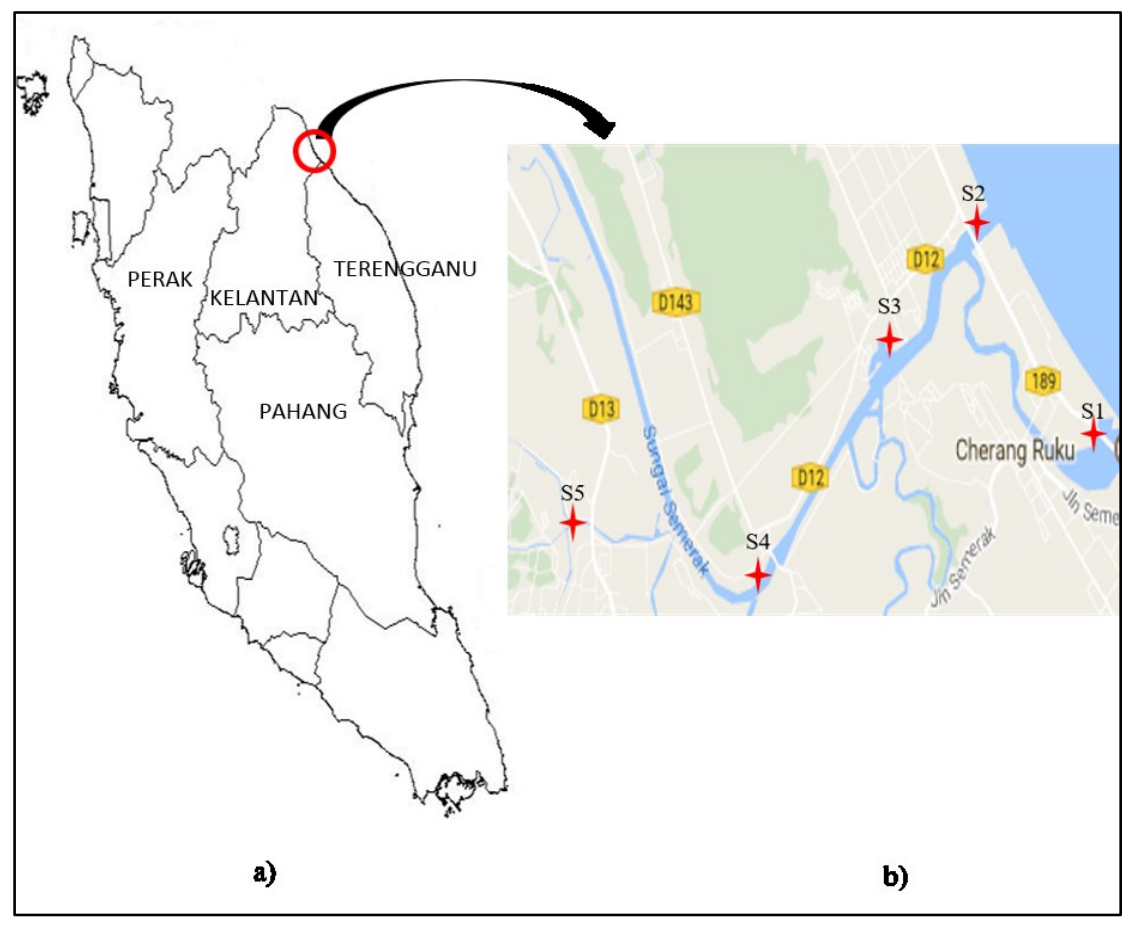

Figure 1. a) Map of Peninsular Malaysia and b) Map of five sampling points along Semerak River. [Scale $1 \mathrm{~cm}=2 \mathrm{~km}]$ 


\section{Control assays: Optical characterization}

\section{Results and Discussion}

Control assays were carried out in order to establish the optimal responses for different substances or antibodies immobilized on the 96 well plates. Figure 2 shows the absorbance for all assays. The effect of BSA-PHEN coating conjugate was studied in Control 1 and it was replaced with coating buffer. Control 2 was performed without BSAPHEN coating conjugate and 4D5. The effectiveness of optimized AP label antibody was studied in Control 3. There was no specific binding observed for all the controls and it was as expected that the normal assay had the highest absorbance. Thus, it can be concluded that all bio elements must present in order to provide better absorbance reading.

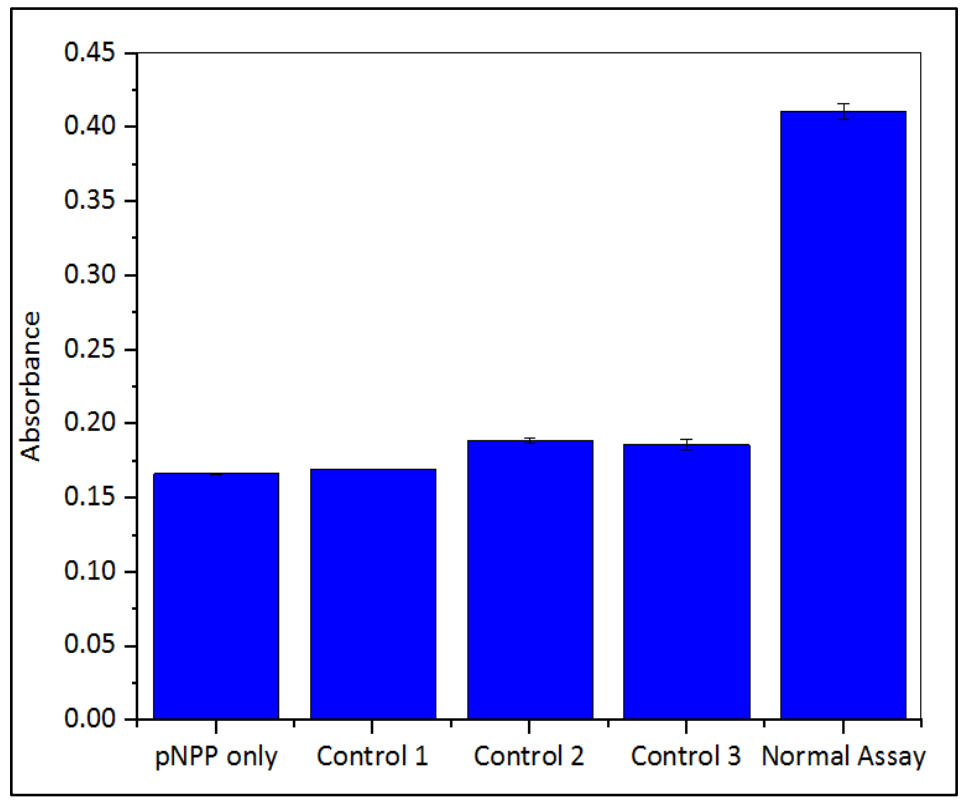

Figure 2. Control assays

\section{Electrochemical characterization}

Electrochemical measurement of the control assay has been conducted without the presence of substrate. Figure 3 and Figure 4 shows the cyclic voltammogram and Nyquist plot of the control assay, respectively. From the voltammogram, low current reading was recorded for all control assays. Redox peaks were appeared in Control 2 and Control 3, which suggested that little redox reaction occurred on the electrode surface, due to formation of thin layers. As expected, normal assay displayed the lowest current reading, which implied high resistance for electron transfer process because of the thick layer appeared due to immobilization of several layers of biomolecules. The $\mathrm{CV}$ results were supported by the EIS results. The resistance recorded for normal assay was the highest, due to slow diffusion of the probe ions onto the gold surface [17]. 
Noor Sheryna et al: ENZYME-LINKED IMMUNOSORBENT ASSAY (ELISA)-BASED-SENSOR FOR DETERMINATION OF BENZO[A]PYRENE IN RIVER WATER USING SCREENPRINTED GOLD ELECTRODE

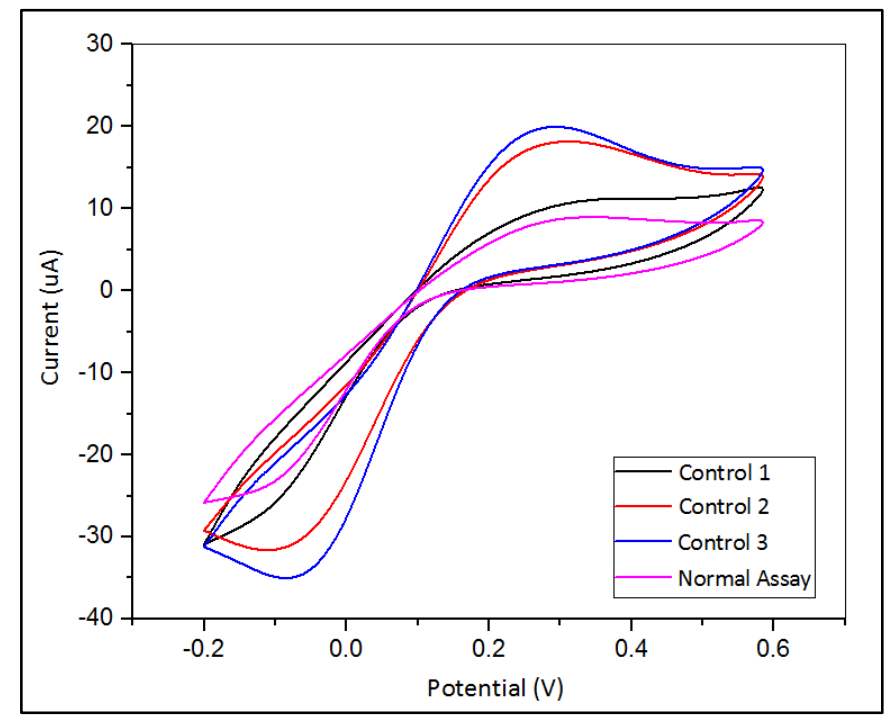

Figure 3. Cyclic voltammograms of control assays on SPGE in $5 \mathrm{mM}$ ferricyanide/ferrocyanide redox probe at scan rate of $50 \mathrm{mV} / \mathrm{s}$

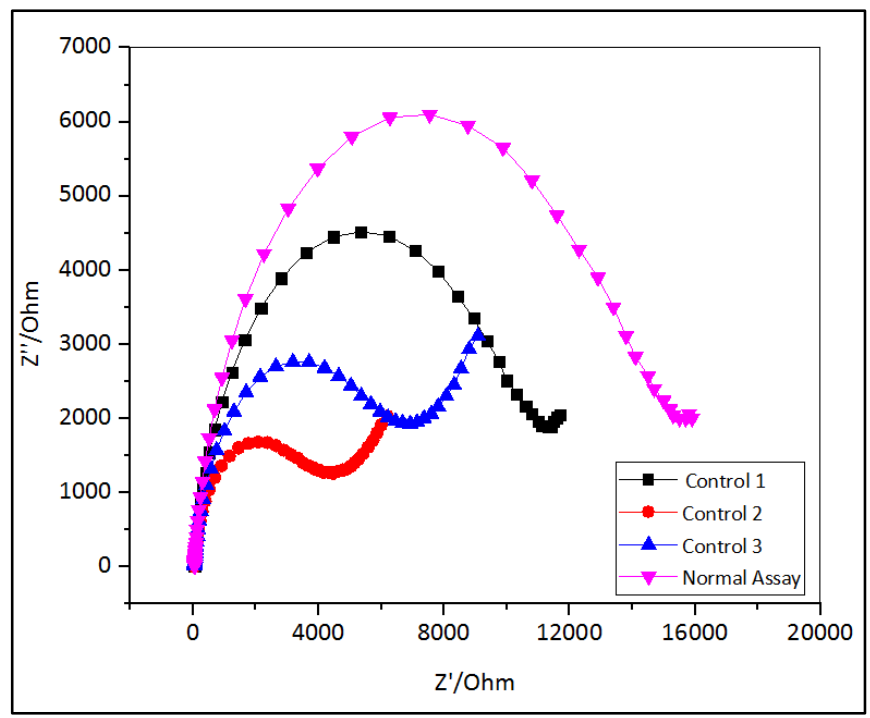

Figure 4. Nyquist plot of control assays on SPGE in $5 \mathrm{mM}$ ferricyanide/ferrocyanide redox probe at $0.025 \mathrm{~V}$ and amplitude of $0.1 \mathrm{~V}$

\section{Indirect competitive assay for benzo(a)pyrene}

The absorbance reading for competitive assay was shown in Figure 5. Different concentrations of BaP were tested to determine the sensitivity of the assay. At $20 \mathrm{ppm}$ of $\mathrm{BaP}$, the absorbance recorded the highest reading, which proved that indirect competitive assay was sensitive at low concentration of $\mathrm{BaP}$. The reading became lower as the concentration of $\mathrm{BaP}$ decreased. 


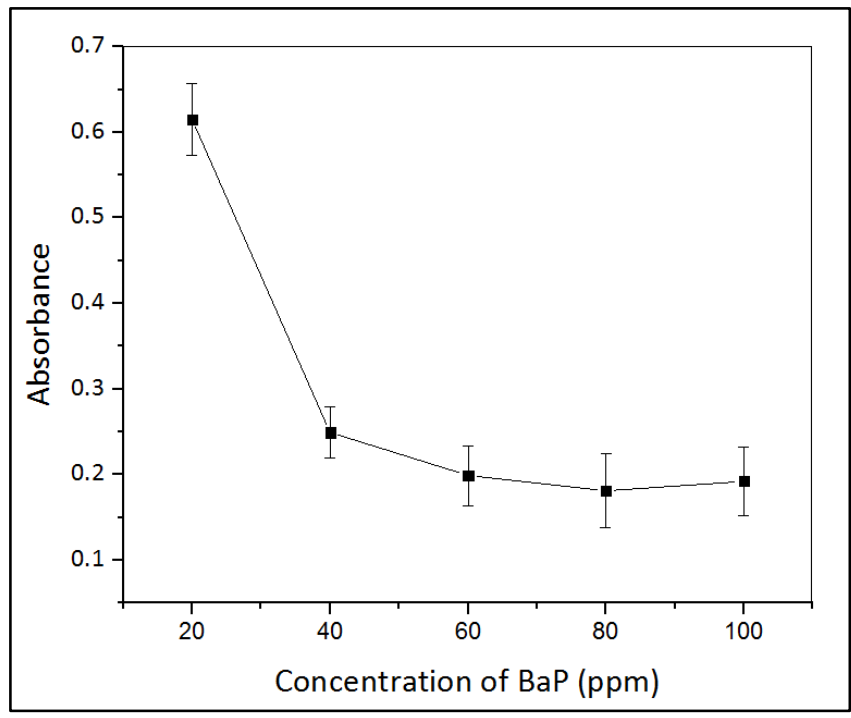

Figure 5. Optical measurement of indirect competitive assay for benzo(a)pyrene

\section{Measurements on river water samples}

The indirect competitive assay was conducted to study the capability of assay to detect $\mathrm{BaP}$ in real water samples. Figure 6 shows the absorbance reading of blank and spiked water samples at five different sampling stations. The lowest absorbance reading was recorded for blank water samples at each station. It is expected because no BaP was presence in the samples. This might be due to the possibility of absence of $\mathrm{BaP}$ in the river water during samples collection. However, after the water samples were spiked with $50 \mathrm{ppm}$ and $100 \mathrm{ppm} \mathrm{BaP,} \mathrm{the} \mathrm{absorbance} \mathrm{reading}$ significantly increased about two times higher than the blank reading at certain sampling points. In addition, the absorbance for water samples spiked with $50 \mathrm{ppm}$ BaP were much higher than $100 \mathrm{ppm}$, where the reading was almost the same. The results proved that the assay was sensitive for BaP detection in lower concentration. This is due to less competition of $\mathrm{BaP}$ molecules to be attracted by the assay. As the concentration increased, more $\mathrm{BaP}$ molecules compete for the binding sites, resulting in low absorbance reading because more binding sites were unoccupied. Compared with lower concentration of $\mathrm{BaP}$, the molecules moved more freely due to many space in the water samples, thus giving enough time for a complete bonding between the assay and the $\mathrm{BaP}$.

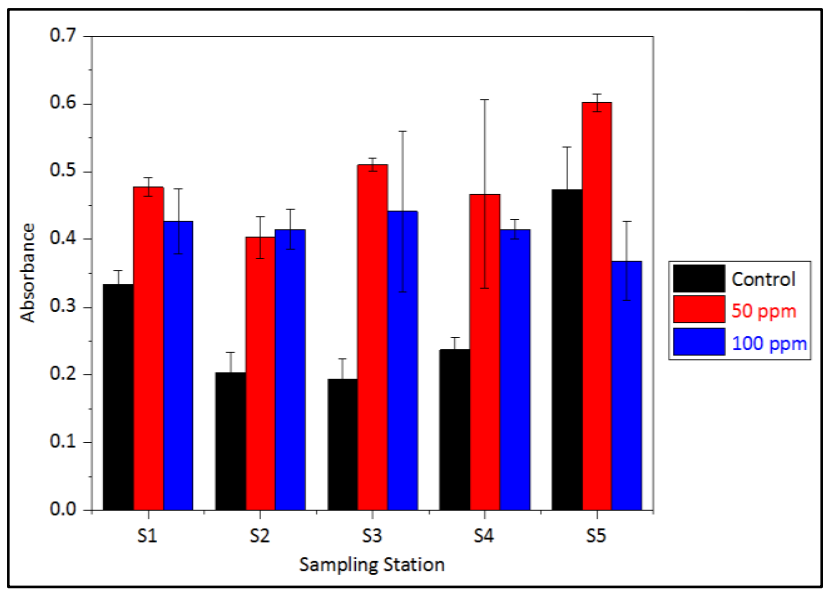

Figure 6. Indirect competitive assay for blank water samples and spiked water samples at five different sampling stations 


\section{Noor Sheryna et al: ENZYME-LINKED IMMUNOSORBENT ASSAY (ELISA)-BASED-SENSOR FOR DETERMINATION OF BENZO[A]PYRENE IN RIVER WATER USING SCREEN- PRINTED GOLD ELECTRODE}

\section{Conclusion}

Biomolecules were successfully immobilized using indirect competitive ELISA. The optical results displayed active enzymatic reactions occurred with the presence of all biomolecules in the assay. The CV and EIS results verified the immobilization of all elements on SPGE, where high current and low resistance were recorded for normal assay. The immunoassay displayed surprising sensitivity for low concentration of $\mathrm{BaP}$. The optical density recorded for 20 ppm $\mathrm{BaP}$ was far higher than other concentrations, which proves the reliability of the immunoassay for detecting the target analytes in lower concentrations of real samples. A test conducted in real water samples verify the sensitivity of the assay, where the optical intensity of lower concentration was higher in most water samples.

\section{Acknowledgement}

The authors would like to extend their gratitude towards the Ministry of Higher Education of Malaysia for financial support through the Research Acculturation Grant Scheme (RAGS) Vote No. 57093 and Universiti Malaysia Terengganu for providing research facilities that were used in this research.

\section{References}

1. World Health Organisation Regional Office for Europe (2000). Polynuclear aromatic hydrocarbons (PAH). Air Quality Guidelines for Europe. Second Edition, Copenhagen: pp. $1-24$.

2. Van Emon, J. M. (2007). Immunoassay and other bioanalytical techniques. Florida, USA: CRC Press.

3. Moina, C. and Ybarra, G. (2012). Fundamentals and applications of immunosensors. In N. H. L. Chiu (Ed.), Advances in immunoassay technology. Rijeka, Croatia: pp. $65-80$.

4. Lewis, J. G., Clifford, J. K. and Elder, P. A. (1990). Monoclonal antibodies to pregnanediol-3-glucuronide: Application to a direct enzyme-linked immunosorbent assay of urine. Steroids, 55: 314 -318.

5. Chung, M. K., Riby, J., Li, H., Iavarone, A. T., Williams, E. R., Zheng, Y. and Rappaport S. M. (2010). A sandwich enzyme-linked immunosorbent assay for adducts of polycyclic aromatic hydrocarbons with human serum albumin. Analytical Biochemistry, 400: 123 - 129.

6. Chung, M. K., Regazzoni, L., McClean, M., Herrick, R. and Rappaport, S. M. (2013). A sandwich ELISA for measuring benzo[a]pyrene-albumin adducts in human plasma. Analytical Biochemistry, 435: 140 - 149.

7. Gui, W. J., Liu, Y. H., Wang, C. M., Liang X. and Zhu, G. N. (2009). Development of a direct competitive enzyme-linked immunosorbent assay for parathion residue in food samples. Analytical Biochemistry, 393: 88 94.

8. Song, J., Yang, H., Wang, Y., Si, W. and Deng, A. (2012). Direct detection of 3-amino-5-methylmorpholino-2oxazolidinone (AMOZ) in food samples without derivatisation step by a sensitive and specific monoclonal antibody based ELISA. Food Chemistry, 135: 1330 - 1336.

9. Perrotta, P. R., Arevalo, F. J., Vettorazzi, N. R. and Zon, M. A. (2012). Development of a very sensitive electrochemical magneto immunosensor for the direct determination of ochratoxin A in red wine. Sensors and Actuators B: Chemical, 162: 327 - 333.

10. Van Emon, J. M., Chuang, J. C., Lordo, R. A., Schrock, M. E., Nichkova, M., Gee, S. J. and Hammock, B. D. (2008). An enzyme-linked immunosorbent assay for the determination of dioxins in contaminated sediment and soil samples. Chemosphere, 72: $95-103$.

11. Barcelo, D., Oubina, A., Salau, J. S. and Perez, S. (1998). Determination of PAHs in river water samples by ELISA. Analytica Chimica Acta, 376: 49 - 53.

12. Matschulat, D., Deng, A., Niessner, R. and Knopp, D. (2005). Development of a highly sensitive monoclonal antibody based ELISA for detection of benzo[a]pyrene in potable water. Analyst, 130: 1078 - 1086.

13. Li, K., Woodward, L. A., Karu, A. E. and Li, Q. X. (2000). Immunochemical detection of polycyclic aromatic hydrocarbons and 1-hydroxypyrene in water and sediment samples. Analytica Chimica Acta, 419: 1 - 8.

14. Fahnrich, K. A., Pravda, M. and Guilbault, G. G. (2003). Disposable amperometric immunosensor for the detection of polycyclic aromatic hydrocarbons (PAHs) using screen-printed electrodes. Biosensors and Bioelectronics, 18: $73-82$.

15. Ahmad, A., Lee, P. K. and Jusoh, N. S. (2016). A comparative study of thiols self-assembled monolayers on gold electrode. Middle-East Journal of Scientific Research. 24(6):2152 - 2158. 
16. Ahmad, A. and Moore. E. (2012). Electrochemical immunosensor modified with self-assembled monolayer of 11-mercaptoundecanoic acid on gold electrodes for detection of benzo[a]pyrene in water. Analyst, 137: 5839 5844.

17. Mishra, S. K., Kumar, D. and Biradar, A. M. (2012). Electrochemical impedance spectroscopy characterisation of mercaptopropionic acid capped $\mathrm{ZnS}$ nanocrystal based bioelectrode for the detection of the cardiac biomarker-myoglobin. Bioelectrochemistry, 88: 118 - 126. 